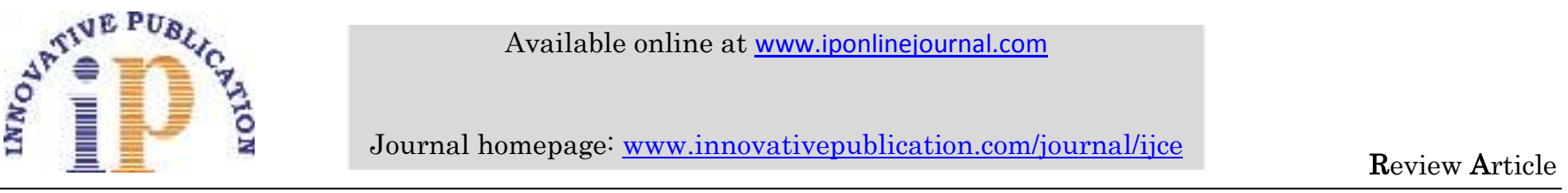

\title{
Resin based core bguild up materials - A review
}

\author{
Gitanjali Singh $^{1 *}$, Lalit C.Boruah ${ }^{2}$, Akanksha Bhatt $^{3}$, Swikriti Agrawal ${ }^{4}$ \\ ${ }^{1,4}$ MDS, ${ }^{2}$ Professor, ${ }^{3}$ Reader, ${ }^{1-4}$ Dept. of Conservative and Endodontics, ${ }^{1-4}$ Babu Banarasi Das College of Dental Sciences, Lucknow, Uttar \\ Pradesh, India
}

\begin{abstract}
A core build up is a restoration placed in a severely damaged tooth in order to restore the structural balance, functional efficiency and aesthetic harmony of the dentition (including oro-facial structures). In order to achieve these criteria, certain factors should be kept into consideration such as: it should protect the remaining tooth from fracture, it should have sufficient compressive strength to resist intra-oral forces, sufficient flexural strength to prevent core dislodgement during function, biocompatibility with the surrounding tissues, ease of manipulation, ability to bond to tooth structure, pins and posts, dimensional stability.

To compensate its drawbacks and to enhance its durability, certain materials have been introduced in order to fulfil most of its criteria. Certain materials such as amalgam, resin based core build up materials, glass ionomer cements and others have been introduced.

These resin based core build up materials met most of its demands which is required in order to fulfil its criteria for an ideal core build up materials. Most of the resin based core build-up materials placed in increments in order to cure completely but now a days few of its materials can be placed in bulk such as Bulk Flow materials and some materials releases fluoride such as Fluorocore, Absolute dentin core build up composite, Pulpdent Hardcore.

Therefore the review of this literature could be a helpful for dentists to use these new promising restorative materials with long term clinical outcome.
\end{abstract}

Keywords: Microhardness, Flowcore, Biocompatibility.

\section{Introduction}

A core build up is a restoration placed in a severely damaged tooth in order to restore the structural balance, functional efficiency and aesthetic harmony of the dentition (including oro-facial structures). ${ }^{1} \mathrm{An}$ ideal core build up material should have physical properties similar to those of tooth structure as a restored tooth tends to transfer stress differently than an intact tooth, where the occlusal biting loads are transferred to dentin as compression that is distributed over a large internal volume of tooth structure reducing local stress. ${ }^{2}$ In order to achieve these criteria, certain factors should be kept into consideration such as: it should protect the remaining tooth from fracture, it should have sufficient compressive strength to resist intra-oral forces, sufficient flexural strength to prevent core dislodgement during function, biocompatibility with the surrounding tissues, ease of manipulation, ability to bond to tooth structure, pins and posts, dimensional stability.

To compensate its drawbacks and to enhance its durability, certain materials have been introduced in order to fulfil most of its criteria. Certain materials such as amalgam, resin based core build up materials, glass ionomer cements and others have been introduced. ${ }^{3}$ But now a days, resin based core build up materials proved to be more demanding because of its high efficiency and low drawbacks. Resin composites offer various advantages including high strength, fluoride release, ease of manipulation and also enhance the ability to reproduce the shade and translucency of natural teeth. However, microleakage may occur and the ability of composites to absorb moisture makes their dimensional stability unsatisfactory. ${ }^{4,5}$

These resin based core build up materials met most of its demands which is required in order to fulfil its criteria for an ideal core build up materials. Most of the resin based core build-up materials placed in increments in order to cure completely but now a days few of its materials can be placed in bulk such as Bulk Flow materials and some materials releases fluoride such as Fluorocore, Absolute dentin core build up composite, Pulpdent Hardcore. Some of them are cured and bonded in an integrated form i.e., post, tooth and core together.

Most of the resin based core build up materials are hydrophobic such as Filtek Silorane restoration and to overcome its effect Spee dee build up material introduced in the market which is favourable in the moist oral conditions. Most of the materials can be cured upto $2 \mathrm{~mm}$ depth but Clearfil Photocore completely cures upto a depth of $9 \mathrm{~mm}$ which is a unique property. Since resin based core build up materials completely depends on the curing factors, therefore, Bright Flowcore is specially designed for areas where light is difficult to reach as it ensures polymerisation in all parts due to its dual curing properties. Since, most of the materials are meant for core build up materials but Bright flowcore can be used both as core build up materials and post cementation. These resin based core build up materials can be placed both in vital and non -vital teeth.

\footnotetext{
*Corresponding Author: Gitanjali Singh, Dept. of Conservative \& Endodontics, Babu Banarasi Das College of Dental Sciences, Lucknow, Uttar Pradesh, India

Email: gitanjalisingh1992@gmail.com

http://doi.org/ 10.18231/j.ijce.2019.018
} 
Therefore, different resin based core build up materials introduced in the market and thereby its recent developed techniques counteract few drawbacks of its previously introduced materials.

There are many factors which affect the strength of the core materials such as filler particle size i.e., bigger the filler particle size, more the strength of the core materials; filler loading i.e., more the number of filler particles increases the strength of the core materials and thereby reduces volumetric shrinkage accompanied by lower stress values which leads to high bond strength; ${ }^{6}$ intensity and distance of the incident light i.e., more the intensity and lesser the distance increases the strength of the core materials; increment thickness i.e., it should be $2 \mathrm{~mm}$ thick so as to allow light to pass through the composite resin for proper polymerisation (since curing depth and microhardness are inversely related with thickness). An inadequate curing degree affects the chemical and physical properties of the composites such as water absorption, discolouration, wear resistance, strength, elution of the possible irritant, toxicity, hardness, marginal breakdown, bond between the tooth, adhesive and restoration.

In order to minimise these effects, a composite resin should be cured to a high degree and to an appropriate depth as well. The effectiveness of fiber reinforcement Thus, recently developed resin based core build up materials are efficiently effective in most of the cases. The effectiveness of fiber reinforcement is dependent on many variables including the resins used, the quantity of fiber in the resin matrix,${ }^{7,8}$ length of fibers, ${ }^{8}$ form of fibers, ${ }^{9}$ orientation of fibers, ${ }^{10}$ adhesion of fibers to the polymer matrix ${ }^{11}$ and impregnation of the resin. ${ }^{12}$

\section{Factors affecting the strength of the core materials}

1. Filler particle size

2. Filler loading

3. Polymerisation initiator concentration

4. Monomer type

5. Amount of monomer

6. Silane coupling agent

7. Shade and translucency of the material

8. Intensity and distance of the incident light

9. Wavelength of the light

10. Irradiation times: Irradiation time should be 40 seconds which produces greater microhardness values but a further increase in exposure time from 40-60 seconds did not result in significant microhardness improvement.

Total energy (intensity x exposure time) is important in the depth of cure, it has some disadvantages such as temperature rise and pulpal effects because of the heat.

11. Design and size of the light guide

12. Increment thickness: It should be $2 \mathrm{~mm}$ thick so as to allow light to pass through the composite resin for proper polymerisation.
Curing depth and microhardness were inversely related with thickness. Thus, it is recommended to apply composite in the layering technique with $2 \mathrm{~mm}$ thickness in each layer.

An inadequate curing degree affects the chemical and physical properties of the resin composite such as water absorption, discoloration, wear resistance, strength, elution of the possible irritant, toxicity, hardness, marginal breakdown, bond between the tooth, adhesive and the restoration. In order to minimise these undesirable effects, a composite resin should be cured to a high degree and to an appropriate depth as well.

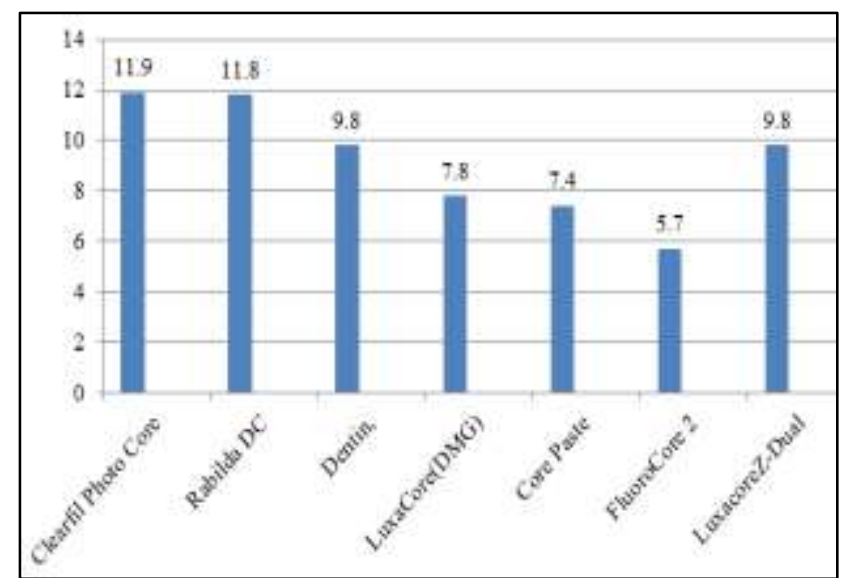

Fig. 1: Cutting characteristics of diffrerent rein based core build up materials

\section{Properties}

1. Cuts like dentin.

2. Extremely high compressive strength. ${ }^{21}$

3. Excellent flow properties.

4. Reliable curing.

5. One material for build up and cementation.

6. Reliable polymerisation: No layering required.

7. Prevents particle agglomeration

8. Better handling characteristics

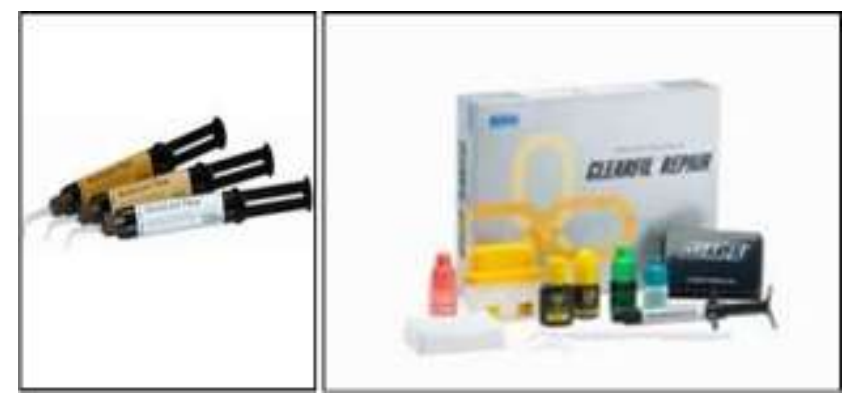

Fig. 2: Multicore Flow; Clearfil Photocore 
Table 1: Comparison of core build-up materials, their compositions and bonding agents ${ }^{26-28}$

\begin{tabular}{|c|c|c|c|c|c|}
\hline Material & Type & Composition & & & Bonding agent \\
\hline Tetric N-Ceram & $\begin{array}{l}\text { Nano-hybrid resin } \\
\text { composite }\end{array}$ & $\begin{array}{l}\text { Urethane dimethacrylate, ethoxylated Bis-EMA, } \\
\text { Bis-GMA(18.8wt } \%) \text {, Barium glass filler, } \\
\text { Ytterbium trifluoride, Mixed oxide }(63.5 \mathrm{wt} \%) \text {, } \\
\text { Polymer(17wt } \%) \text {, Additives, Catalysts, Stabilisers } \\
\text { and Pigments }(0.7 \mathrm{wt} \%)\end{array}$ & & & Tetric n-Bond \\
\hline Clearfil Photocore & $\begin{array}{lr}\text { Light cured Core } \\
\text { build-up Hybrid } \\
\text { Composite }\end{array}$ & $\begin{array}{l}\text { Silinated silica filler, Silinated barium glass filler, } \\
\text { triethylene glycol dimethacrylate, bisphenol-A } \\
\text { diglycidylmethacrylate(Bis-GMA), } \\
\text { dicamphoroquinone, catalysts, accelerators and } \\
\text { other filler contents }\end{array}$ & & & $\begin{array}{l}\text { Clearfil SE } \\
\text { Bond }\end{array}$ \\
\hline MultiCore Flow & $\begin{array}{l}\text { Self-cured } r \text { core } \\
\text { build-up composite } \\
\text { with light cured } \\
\text { option }\end{array}$ & $\begin{array}{l}\text { Wt\% } \\
\text { Bis-GMA, Urethane dimethacrylate, Triethylene } \\
\text { glycol dimethacrylate, } \\
\text { Barium glass fillers, Ba-Al-fluorosilicate glass, } \\
\text { highly dispersed silicon dioxide, } \\
\text { Ytterbium trifluoride, } \\
\text { Catalysts, Stabilisers, Pigments }\end{array}$ & $\begin{array}{c}\text { Base } \\
28.1 \\
\\
54.9 \\
\\
\\
16.4 \\
0.6\end{array}$ & $\begin{array}{c}\text { Catalyst } \\
28.4 \\
54.4 \\
\\
\\
16.2 \\
1\end{array}$ & Adhe SE \\
\hline $\begin{array}{l}\text { LuxaCore Z-Dual } \\
\text { Automix }\end{array}$ & $\begin{array}{l}\text { Dual -cured core } \\
\text { build-up composite }\end{array}$ & $\begin{array}{l}\text { Bis-GMA based dental resins ( } 28 \%) \text {, inorganic } \\
\text { filler }(70 \%) \text {, additives, pigments, catalysts }(2 \%)\end{array}$ & & & Luxabond \\
\hline
\end{tabular}

\section{Conclusion}

Various resin based core build up materials are comparable in number of ways as Luxacore has high compressive strength and flow properties whereas Tetri Evo Ceram doesn't have good flowability. Bright flowcore can be used even in poor accessible areas where light is difficult to reach. Fluorocore 2 has high compressive strength, tensile strength and flexural strength whereas Rock core has least flexural toughness. Spee Dee behaves favourably in moist oral conditions whereas other materials are hydrophobic in nature where chemical reaction is inhibited in the presence of moisture.

\section{Source of Funding}

None.

\section{Conflict of Interest}

None.

\section{References}

1. Combe EC,Shagluof AM, Watts DC,Wilson NH. evaluated mechanical properties of direct core build-up materials. Dent Mater 1999;15:158-65.[PubMed]

2. Nujella BP, Choudhary MT, Reddy SP, Kumar MK, Gopal T. Evaluated comparison of shear bond strength of aesthetic restorative materials. Contempt Clin Dent 2012;3:22-6

3. Cohen BI, Pangnillo MK, Newman I, Musikant BL, Deutsch AS. 92 Evaluated fracture strength of three core restorative materials supported with spilt shank post. J Oral Rehabil 2000;27:83-

4. Ferracane JL. Evaluated current trends in dental composites. Dent Mater 2011;27(1):29-38

5. Puckett AD, Fitchie JG, Kirk PC, Gamblin J Dent Clin North Am 2007;51:659-75

6. El Sahn NA, El Kassas DW, El Damanhoury HM, Fahmy OM, Gomaa H, Platt JA. Evaluated effect of c-factor on microtensile bond strength of low shrinkage composites. Oper Dent 2011;36:281-92
7. Vallitu PK, Lassila VP, Lappalainen R. Eavluated the effect of fiber concentration on fracture resistance. J Prosthet Dent 1994;71:607-12

8. Stipho HD. Evaluated repair of acrylic resin denture base reinforced with glass fiber, J Prosthet Dent 1998;80:546-50

9. Ladizesky NH, Cheng YY, Chow TW, Ward IM. Evaluated acrylic resin reinforced with chopped high performance polyethylene fiber properties and denture construction, Dent Mater 1993;9:128-35

10. Dyer SR, Lassila LVJ, Jokinen M, Vallitu PK. Evaluated effect of fiber position and orientation on fracture load of fiber reinforced composite, Dent Mater 2004;20:947-55

11. Vallitu PK. Evaluated the effect of void space and polymerisation time on transverse strength of acrylic glass fiber composite. J Oral Rehabil 1995;22:257-61

12. Miettinen VM, Vallittu PK. J Prosthet Dent 1997;77:531-4 evaluated water sorption and solubility of glass fiber reinforced denture polymethyl methacrylate

13. Bitter K, Glaser C, Newmann K, Blunk U, Frankenberger R, Evaluated resin-dentin interface morphology and bond strength evaluation of core materials for one stage post- endodontic restorations 9;(2014)784-90

14. Tay FR, Pashley DH. Evaluated monoblocks in root canals: a hypothetical or tangible goal. J Endod 2007;33(4):391-8

15. Bitter K, Perdigao J, Exner M, Neumann K, Kielbassa A, Evaluated reliability of fiber post bonding to root canal dentin after simulated clinical function in-vitro. Sterzenbach $G$ Oper Dent 2012;37:4 397-405

16. Bitter K, Perdigao J, Hratwig C, Neumann K, Kielbassa AM. Evaluated nanoleakage of luting agents for bonding fiber posts after simulated clinical function in-vitro. $J$ Adhes Dent 13(1):61-69

17. Ilie N, Simon A. Evaluated effect of curing mode on the micromechanical properties of dual cured self adhesive resin cements, Clin Oral Investig 2012;16;(2):505-12

18. Bitter. K., Glaser. C, Neumann. K, Blunck. U and Frankenberger. R. Evaluated resin- dentin interface morphology and bond strength evaluation of core build materials for one stage post endodontic restorations. Plos One 2014;9(2)

19. Furtos G, Baldea B., Silaghi-Dumitresco, L., Moldovan M., Prejmerean, C. And Nica, L. Evaluated influence of inorganic 
filler content on the radiopacity of dental resin cements. Dent Mater J 2012;31:(2)266-72

20. Wegenhaupt, F.J., Betschart, J and Attin, T. Evaluated effect of sodium hypochlorite contamination on microhardness of dental core build-up materials. Dent Mater J 2010;29:(4)469-74.
How to cite this article: Singh $G$, Boruah LC, Bhatt A, Agrawal S. Resin based core bguild up materials - A review. Indian J Conserv Endod 2019;4(3):79-82. 